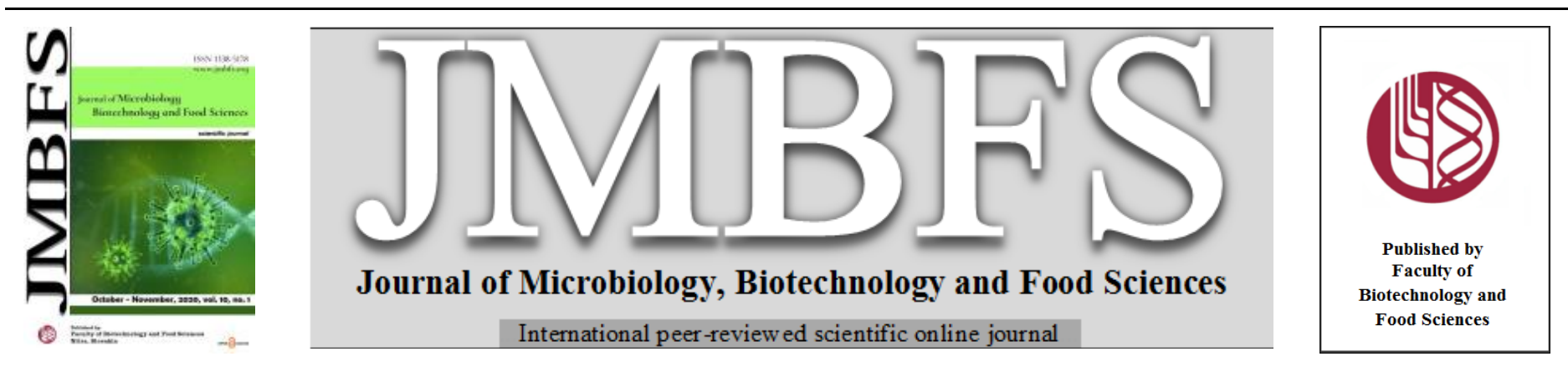

\title{
PURIFICATION AND CHARACTERIZATION OF AN ENDOGLUCANASE PRODUCED FROM Streptomyces sp. STRAINBPNG23
}

\author{
Azzeddine Bettache ${ }^{* 1,2}$, Estelle Copinet ${ }^{2}$, Zahra Azzouz $^{1}$, Nawel Boucherba ${ }^{1}$, Cilia Bouiche ${ }^{1}$, Samir Hamma ${ }^{1}$, Rima Maibeche ${ }^{1}$, \\ Francis Duchiron ${ }^{2}$, Said Benallaoua ${ }^{1}$
}

Address(es): Azzeddine Bettache

${ }^{1}$ Laboratoire de Microbiologie Appliquée, faculté des sciences de la nature et de la vie, université de Bejaia, 06000 Bejaia, Algéria.

${ }^{2}$ UMR FARE 614 INRA/URCA. Laboratoire de Microbiologie Industrielle, UFR Sciences, université de Reims Champagne-Ardenne, Moulin de la Housse, 51687

Reims, France.

*Corresponding author: bettache84@hotmail.fr

doi: 10.15414/jmbfs.2020.10.2.284-288

\section{ARTICLE INFO}

Received 25. 5. 2018

Revised 21. 6. 2020

Accepted 29. 6. 2020

Published 1. 10. 2020

Regular article

OPEN $\partial_{\text {ACCESS }}$

\begin{abstract}
Streptomyces sp. strain BPNG23 produces five endoglucanases: endo1, endo 2, endo 3, endo 4 and endo 5.The endo2 has been purified and characterized by two subsequent purification steps with ultrafiltration and anion exchange chromatography. The specific activity of the endoglucanase has been found to be $380.65 \mathrm{U} / \mathrm{mg}$. The molecular weight to the endoglucanase 2 has been estimated with sodium dodecyl sulfate-polyacrylamide gel electrophoresis, revealing that this isoenzyme is a $66 \mathrm{KDa}$ monomeric enzyme. It showed an optimum temperature and $\mathrm{pH}$ values respectively of 6.0 and $50{ }^{\circ} \mathrm{C}$. It was thermostable, it exhibited a half-life time $6 \mathrm{~h}$ with a temperature of $50^{\circ} \mathrm{C}$, the enzyme was activated by several metal ions $\mathrm{Mn}^{+2}, \mathrm{NH}^{4+}, \mathrm{Zn}^{2+}, \mathrm{Ca}^{2+}, \mathrm{Fe}^{2+}, \mathrm{Ni}^{2+}$ and $\mathrm{Co}^{2+}$. It presents a higher affinity towards carboxymethyl cellulose (CMC) with a $\mathrm{K}_{\mathrm{m}}$ of $6.37 \mathrm{mg} / \mathrm{mL}$ and Vmax of $0.056 \mu \mathrm{mol} / \mathrm{mn}$. This the first of a study of purification and characterization of an endoglucanase produced by a newly isolated actinobacteria strain in Kabylia region (Algeria).
\end{abstract}

Keywords: Streptomyces, endoglucanase, purification, characterization, wheat bran

\section{INTRODUCTION}

Cellulose is one of the most abundant organically produced compounds available in the world and is a kind of sustainable energy which human beings are able to easily utilize (Bataillon $\boldsymbol{e t}$ al., 2000). The previous research studies have shown the occurrence of several various bacterial and fungal cellulases which can be classed in three different types: endoglucanases (EC 3.2.1.4), exoglucanases (EC 3.2.1.91) and $\beta$-glucosidases (EC 3.2.1.21) (Battan et al., 2007). However, a complete degradation of cellulose implies a complex interaction with different cellulolytic enzymes. It was widely agreed and accepted for three types of cellulolytic enzymes which include endoglucanases (EC 3.2.1.4) hydrolyze randomly internal glycosidic linkages in cellulose, whereas exoglucanases cleave long chains of the ends in the progressive chain, $\beta$-glucosidases transform cellobiose into glucose (Beg, 2001).

Cellulase is used in bio-fuels biomass fermentation, though the process was relatively experiential in the present. Cellulase has been used for a treatment of phytobezoars, as a form for cellulose bezoar located in the human stomach (Béguin and Aubert, 1994). Cellulases attracted attention with their various applications in both medical and industrial applications. For example, they have been used in decreasing the high level of serum cholesterol, by improving nutrient quality and digestibility (Blanco et $\boldsymbol{a l}$., 1999), in animal feed (Mandels, 1985), in waste/water management (Biely and Mackenzie, 1986), in textile ( biodegradable textile and producing washed look of denim, etc.) (Cavaco-Paulo, 1998; Celestino and Felix, 2006), in the pulp and the paper industry, and starch transformation (Beg, 2001), in breach and wine-making and in house keep washing detergents (Mandels, 1985).

Actinobacteria are Gram positive filamentous soil bacteria which as the first producers from a large variety of antibiotics and the important bioactive compounds and enzymes, among them major industrial enzymes implicated in lignocelluloses conversion (Blanco et al., 1999). The degradation of cellulose, hemicelluloses and lignin, that are abundant of plants, various strains from the Streptomyces genus were studied, and were found as good cellulase producers (Budihal and Patil, 2016; Shaik et al., 2017; Wu et al., 2017; Gobalakrishnan and Sivakumar, 2017; Schrempf, 2017; Kumarand Henehan, 2017).

Commercial production and efficient utilization of cellulases are infested with many problems. For increasing the efficiency of the process, we could search of a more active cellulase or developing low-cost methods of pretreatment for the substrates, by making more accessible them suitable for enzymatic degradation. Thus, to mitigate of this problem, the purpose of the present study has been purified and characterized an endoglucanase producing by Streptomyces sp. strain BPNG23.

\section{MATERIAL AND METHODS}

\section{Microbial strain}

Strain BPNG23 was isolated from forest soil of Bejaia in Kabylia region (Algeria). The strain was selected for its potential to produce endoglucanase enzymes. The 16S rRNA gene sequence of the strain BPNG23 has been deposited in GenBank Streptomyces under accession number "JQ678705".

\section{Preparation of extracellular crude enzyme}

For the cellulases production, 3\% pre-culture of Streptomyces sp. strain BPNG23 was cultured in medium based on wheat bran: yeast extract $(10 \mathrm{~g} / \mathrm{L}), \mathrm{NH}_{4} \mathrm{Cl}(2.5$ $\mathrm{g} / \mathrm{L}), \mathrm{MgSO}_{4}(0.4 \mathrm{~g} / \mathrm{L}), \mathrm{NaCl}(2 \mathrm{~g} / \mathrm{L})$ and $10 \mathrm{~g} / \mathrm{L}$ of wheat bran. The $\mathrm{pH}$ was adjusted to 7 and the incubation was performed at $28^{\circ} \mathrm{C}$ at under agitation rate of $100 \mathrm{rpm}$, finally the fermentation broth was centrifuged at $10,000 \times \mathrm{g}$ for 10 minute at $4^{\circ} \mathrm{C}$.

\section{Purification of the enzyme}

The supernatant culture contains secreted cellulases, was concentrated using Minimate PALL system, (France, 10KDa cut-off membrane Millipore, $20 \mathrm{~cm}$ x $3.8 \mathrm{~cm} \times 1.8 \mathrm{~cm})$. The concentrated crude enzyme $(2 \mathrm{~mL})$ was applied to AKTA Explorer 10 (England) equipped with a strong anion-exchange column Q Sepharose (Hitrap, $5 \mathrm{~mL}$ ) equilibrated with $50 \mathrm{mM}$ Tris- $\mathrm{HCl}$ buffer $(\mathrm{pH} 8.5)$. Protein was eluted using $\mathrm{NaCl}$ gradient $(0-1 \mathrm{M})$ in $50 \mathrm{mM}$ Tris- $\mathrm{HCl}$ buffer $(\mathrm{pH}$ $8.5)$ at a flow rate of $4 \mathrm{~mL} / \mathrm{min}$. A total of number fractions $(2 \mathrm{~mL}$ in each test tube) have been collected and assessed by enzyme activity with protein quantification. 


\section{Analytical methods}

\section{SDS-PAGE and zymogram analysis of endoglucanase}

The crude enzyme $(25 \mu \mathrm{g})$ in the sample treatment buffer has been boiled for 5 min and was submitted to sodium dodecyl sulfate-polyacrylamide ge electrophoresis utilizing $10 \%$ polyacrylamide. Electrophoresis was carried out using Mini-Gel Electrophoresis unit (Biorad, France).This analysis was performed by Laemmli method, 1970. After the electrophoresis, $0.1 \%$ of CMC has been incorporated into running polyacrylamid gel, on completion by electrophoresis; the gel has been cut into two parts. One part has been utilised for Coomassie brilliant blue R-250 staining and the other has been utilised for zymography. This analysis was performed using the basic protocol; the gel was soaked in triton X-100 at $2.5 \%(\mathrm{w} / \mathrm{w})$ for $30 \mathrm{~min}$, and then incubated in the phosphate buffer $50 \mathrm{mM}\left(\mathrm{pH} \mathrm{7.0)}\right.$ ) for $30 \mathrm{~min}$ at $50^{\circ} \mathrm{C}$. The gel was reavaled using $0.1 \%$ Congo red solution for $15 \mathrm{~min}$ at room temperature $\left(15^{\circ} \mathrm{C}\right)$, thereafter washing $1 \mathrm{M} \mathrm{NaCl}$ and inserted in $0.5 \%$ acetic acid for exposing the endoglucanase active bands that contrasts to the dark background.

\section{Enzymatic assay and protein quantification}

The supernatant of the fermentation broth has been used for determining the endoglucanase activity; it was assayed using $20 \mathrm{~g} / \mathrm{L}$ (w/v) carboxymethy cellulose such as the substance that has been suspended in a $50 \mathrm{mM}$ sodium phosphate buffer ( $\mathrm{pH} 7.0)$. The reaction mixture has been compounded of $250 \mu \mathrm{l}$ substrate and $250 \mu$ of crude enzyme. The reaction mixture has been incubated at $50^{\circ} \mathrm{C}$ during $30 \mathrm{~min}$. The releasing reducing sugar has been measured using the 3,5- dinitrosalicylic acid (DNS). The reducing sugar liberated has been measured at $540 \mathrm{~nm}$, utilizing a standard curve with glucose absorbance generated as the standard, in which one unit (U) of endoglucanase activity has been defined as the amount of enzyme that Releases $1 \mu \mathrm{mol}$ glucose $/ \mathrm{min} / \mathrm{mL}$ in the above conditions. Protein has been quantified using Bradford method (Bradford, 1976), utilizing bovine serum albumin as the standard. Enzymatic activity and protein assays have been performed in triplicate.

\section{Characterization of the enzyme}

\section{Molecular weight estimation}

The molecular weight for the purified protein has been evaluated using the method of Laemmli, 1970 employing sodium dodecyl sulphate-polyacrylamide gel electrophoresis.

\section{Effect of $\mathrm{pH}$ and temperature}

The endoglucanase activity has been evaluated at various temperatures (ranging from $30-70^{\circ} \mathrm{C}$ ) and $\mathrm{pH}$ values $(\mathrm{pH} 4-5$, sodium acetate; $\mathrm{pH}$ 6-7, sodium phosphate $\mathrm{pH} 8-9$ and 10 , Tris- $\mathrm{HCl}$ ) under the method previously described.

\section{Thermostability}

Thermostability of endoglucanase has been established by incubating the samples with substrate in a $50 \mathrm{mM}$ sodium phosphate buffer $(\mathrm{pH} \mathrm{6.0)}$ from temperatures of 40,50 and $60^{\circ} \mathrm{C}$ with an interlude period between 1 and 10 hours. The residual endoglucanase has then been determined by the DNS method.

\section{Substrate specificities}

The substrate specificities for the endoglucanase purified were established with the following substrates: 20g/Lbirchwoodxylan, 20g/Lavicel, 20g/L cellobiose and $20 \mathrm{~g} / \mathrm{L}$ carboxymethyl cellulose prepared in $50 \mathrm{mM}$ sodium phosphate buffer (pH 7.0).

\section{Effect of metal ions and reagents on endoglucanase activity}

For the investigation the effects of diverse metal ions on endoglucanase activity, the solutions with $5 \mathrm{mM}$ of $\mathrm{Na}+, \mathrm{Mg} 2+, \mathrm{Ca} 2+, \mathrm{Mn} 2+, \mathrm{Fe} 2+, \mathrm{Zn}^{2+}, \mathrm{Cu}^{2+}, \mathrm{NH}^{4+}$, $\mathrm{Hg}^{2+}, \mathrm{K}+, \mathrm{Ni}^{2+}, \mathrm{Sr} 2+$ and $\mathrm{Co}^{2+}$ were additioned in the reaction mixtures which contained the purified endoglucanase into $50 \mathrm{mM}$ sodium phosphate buffer $(\mathrm{pH}$ 7. 0), the reaction mixture was considered as control without any additive and the activity of endoglucanase was determined to be $100 \%$. Effect of some inhibitors chelators: ethylenediaminetetraacetic acid (EDTA), sodium dodecyl sulfate (SDS), dithiothreitol (DTT) and phenylmethanesulfonyl fluoride (PMSF) were also tested.

\section{Kinetic parameters}

The effect of carboxymethyl cellulose, varying from 1 to $10 \mathrm{mg} / \mathrm{mL}$ on endoglucanase activity was assessed at optimal assay conditions $\left(50^{\circ} \mathrm{C}, \mathrm{pH} 6.0\right)$. Kinetic parameters were evaluated using linear regression of double-reciprocal plots according to Lineweaver-Burk, and all tests were carried out in triplicate.

\section{RESULTS AND DISCUSSION}

\section{Purification of endoglucanase}

After 7 days of fermentation, the medium was centrifuged and the activity was measured in the culture supernatant. The endoglucanase activity obtained was 1.2 $\mathrm{U} / \mathrm{mL}$, with specific activity of $1.81 \mathrm{U} / \mathrm{mg}$ protein. The culture supernatant was concentrated 20 -fold by ultrafiltration to obtain a final volume of $50 \mathrm{~mL}$. At this step, impurities having a molecular weight equal or less than $10 \mathrm{kDa}$ were eliminated. This explains the decrease of protein in the culture supernatant from $660 \mathrm{mg}$ to $22.5 \mathrm{mg}$ in the retentate. The specific activity after ultrafiltration was $23.11 \mathrm{U} / \mathrm{mg}$ protein. This step improved the purity of the enzyme so that its specific activity was $1.81 \mathrm{U} / \mathrm{mg}$ in crude supernatant. The yield of this purification process was estimated at $43.3 \%$ with a purification factor of 12.76 .

\section{Anion exchange chromatography}

The chromatogram shows seven protein peaks including three with endoglucanase activity for $0.15 \mathrm{M}, 0.35 \mathrm{M}$ and $0.6 \mathrm{M}$ of $\mathrm{NaCl}$ (figure 1). All proteins were eluted once the $\mathrm{NaCl}$ gradient was realized, this, indicate that the protein fractions were retained by the column. The negatively charged proteins are retained on the column while the neutral and positively charged proteins will be eluted first.

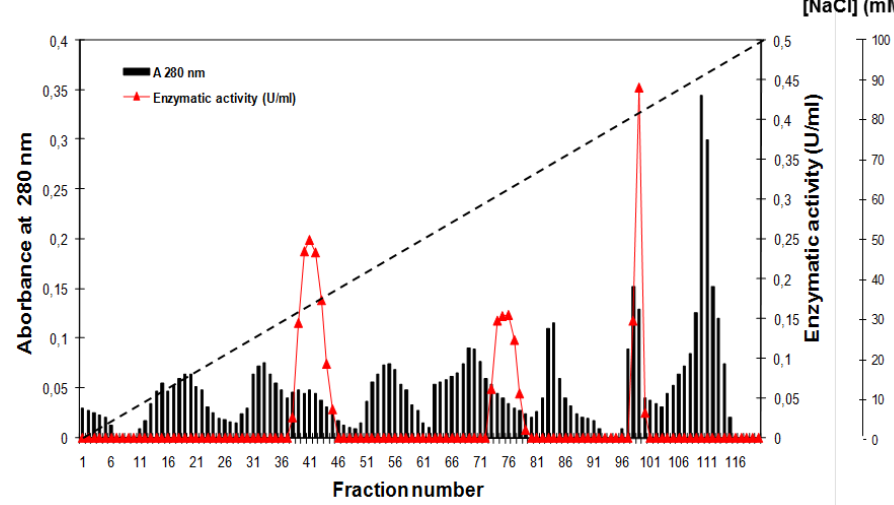

Figure 1Proteins quantification and elution profil of endoglucanase activity on Qsepharose HI Trap 5mL.

A synthesis for a representative purification procedure was presented in table 1 .

Table 1 Purification steps of endoglucanases from Streptomyces sp. strain BPNG23

\begin{tabular}{|c|c|c|c|c|c|c|}
\hline $\begin{array}{l}\text { Purification } \\
\text { steps }\end{array}$ & Volume (mL) & $\begin{array}{c}\text { Total volume } \\
\text { activity (U) }\end{array}$ & $\begin{array}{l}\text { Total proteins } \\
\text { (mg) }\end{array}$ & $\begin{array}{c}\text { Specific activity } \\
\text { (U/mg) }\end{array}$ & Yield (\%) & $\begin{array}{c}\text { Purification } \\
\text { Factor }\end{array}$ \\
\hline $\begin{array}{l}\text { Culture } \\
\text { supernatant }\end{array}$ & 1000 & 1200 & 660 & 1.81 & 100 & 1 \\
\hline Ultrafiltration & 50 & 520 & 22.5 & 23.11 & 43.3 & 12.76 \\
\hline $\begin{array}{l}\text { Anion exchange } \\
\text { chromatography }\end{array}$ & 50 & $\begin{array}{c}\text { A: } 12 \\
\text { B: } 7.5 \\
\text { C: } 19.5\end{array}$ & $\begin{array}{c}0.037 \\
0.048 \\
0.22\end{array}$ & $\begin{array}{c}324.32 \\
154 \\
88.6\end{array}$ & $\begin{array}{c}2.3 \\
1.44 \\
3.75\end{array}$ & $\begin{array}{c}14.03 \\
6.66 \\
3.83\end{array}$ \\
\hline
\end{tabular}

Anion exchange chromatography was the supreme step in the purification of endoglucanases, the yield decreased respectively to $2.3,1.44$ and $3.75 \%$ for the three proteins A, B and C. After each purification step the specific activity of the enzyme increased, the final yield was increased more than 14-fold. It was previously reported than ammonium sulfate precipitation following with anion exchange chromatography gives a purification yield of 9.06 with a Bacillus sp strain M-9 (Bajaj et al., 2009)and 17.5 for Cellulomonas sp. YJ5 (Theberge et al., 1992)

Enzyme characterization 


\section{Molecular weight}

There were five distinct endoglucanases were detected on zymogram analysis, called: Endo1, Endo2, Endo3, Endo4 and Endo5, in which the molecular weights were $97 \mathrm{KDa}, 66 \mathrm{KDa}, 62.5 \mathrm{KDa}, 53 \mathrm{KDa}$ and $50 \mathrm{KDa}$, respectively, more details are given in our paper (Bettache et al., 2013). The enzyme purified appears of being homogeneous since it migrated in a single band in SDS-PAGE (figure 2)

From the zymogram and the SDS-PAGE profil, it was found of the molecular weight of the endoglucanase A was $66 \mathrm{KDa}$, which corresponds to endoglucanase 2 found in the concentrated supernatant (figure 2).

Some molecular weights of CMCases produced by various microorganisms were reported: $33 \mathrm{KDa}$ for the CMCase from Bacillus sp (Gupta and Vadehra, 1990), $70 \mathrm{kDa}$ in Neurospora crassa (Yazdi et al., 1990), the endoglucanases obtained from Trichoderma viride have molecular weights of 38, 42, 52 and $60 \mathrm{kDa}$ (Kim et al., 1994), $38 \mathrm{kDa}$ for Thermomonospora (George and Rao, 2001), 38 and 74 $\mathrm{kDa}$ for Anabaena laxa (Gupta et al., 2012).

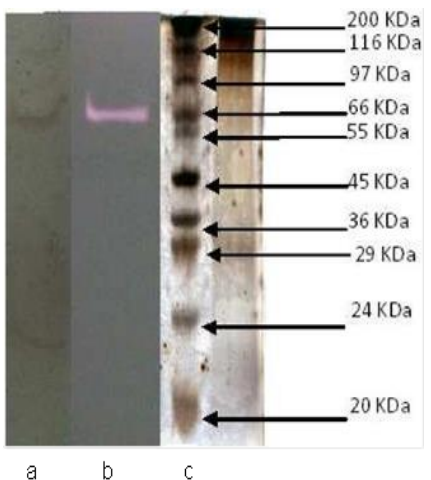

Figure 2 Migration profile of endoglucanase A (SDS-PAGE) and zymogram (a: protein profil; b: Zymogram, c: SIGMA markers)

\section{Effect of pH and temperature on enzyme activity}

The purified endoglucanase showed good stability at $\mathrm{pH}$ 5.0-8.0, it posted optimum activity a $\mathrm{pH} 6$ (figure $3 \mathrm{~b}$ ) and only $27.68 \%$ relative activity a $\mathrm{pH} 9$. The optimum temperature for this endoglucanase activity as shown in Figure $3 \mathrm{~b}$ at $50^{\circ} \mathrm{C}$.

Depending on the optimum temperature, enzymes can be classified such as mesophiles $\left(40-60^{\circ} \mathrm{C}\right)$, thermophilic $\left(50-80^{\circ} \mathrm{C}\right)$ and hyperthermophilic $\left(>80^{\circ} \mathrm{C}\right)$ (Maheshwari and Bhat, 2000), most endoglucanases were stable between 50$55^{\circ} \mathrm{C}$ (Lucas et al., 2001). The optimum CMCase temperature produced by Streptomyces sp. strain B-PNG23 was similar to those produced by $B$ amyloliquefaciens DL-3 (Lee et al., 2008). The thermophilic endoglucanases with optimal activity at $80^{\circ} \mathrm{C}$ were often reported by thermophilic microorganisms such as Fervidobacterium Nodosum (Wang et al., 2010), and Acidothermus cellulolyticus (Lindenmuth and Mcdonald, 2011).

The effect of $\mathrm{pH}$ on the endoglucanase activity of Streptomyces sp. strain BPNG23 was evaluated at $50^{\circ} \mathrm{C}$ in a buffer system. The optimum $\mathrm{pH}$ of the endoglucanase activity of the purified enzyme was 6 . In general, endoglucanases are not active at low pH (Wang et al. 2010; Yu, 2012). The endoglucanase produced by Streptomyces sp. strain BPNG23 was active in a wide $\mathrm{pH}$ range, which proves to be an advantage for use under different reaction conditions or biotechnology processes.
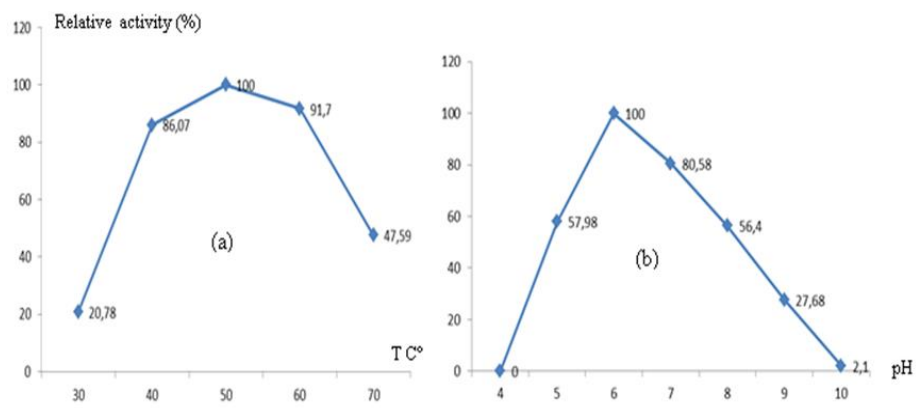

Figure 3 Effect of temperature (a) and $\mathrm{pH}$ (b) on the activity of endoglucanase A

\section{Thermostability}

At $40^{\circ} \mathrm{C}$, the activity was stable it was not significant decrease of endoglucanase activity for $4 \mathrm{~h}$. This enzyme showed a good stability at $50^{\circ} \mathrm{C}$, with a half-life of $6 \mathrm{~h}$. At $60^{\circ} \mathrm{C}$, there was a sharp drop in relative activity $(7.65 \%)$; after $4 \mathrm{~h}$ of incubation, the relative activity decreased dramatically (figure 4). The endoglucanases of Streptomes sp. strain BPNG23 exhibit similar optimal temperatures to those described forFusarium oxysporum $\left(50\right.$ and $\left.55^{\circ} \mathrm{C}\right)$ (Christakopoulos, 1995), but with higher thermal stability.

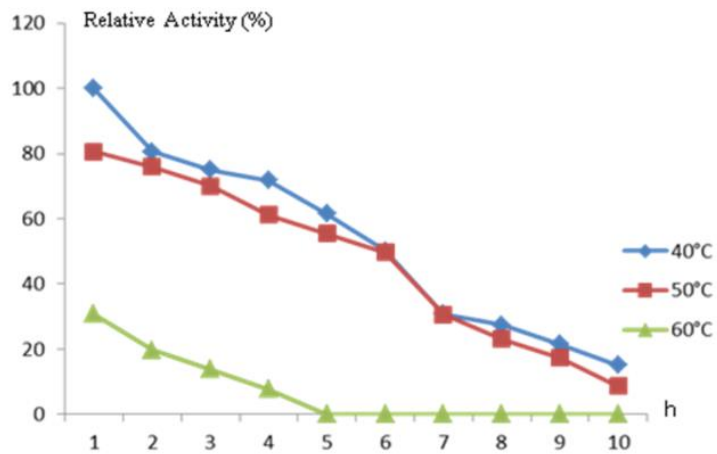

Figure 4 Thermostability of endoglucanase A in the presence of substrate

\section{Substrate specificity}

The results show that the purified endoglucanase has more affinity for CMC with a relative activity of $100 \%$. It also degrades cellobiose with a relative activity of $15.35 \%$. For avicel and birch xylan, endoglucanase has no relative activity (figure 5). The use of a variety of polysaccharides checks that the enzyme purified in the present study was an endoglucanase. The "endo" nature of the endoglucanase was confirmed by its high activity on carboxymethyl cellulose and no hydrolysis of the crystalline cellulose (Béguin and Aubert, 1994) Trichodermareeseiendoglucanase also revealed hydrolytic activity on a wide range of substrates, namely $\beta$-glucan, carboxymethyl cellulose, hydroxyethylcellulose, xylan, methylumbelliferyl- $\beta$-D-cellobioside and methylumbelliferyl- $\beta$-D-lactoside(Domain et al., 1998).

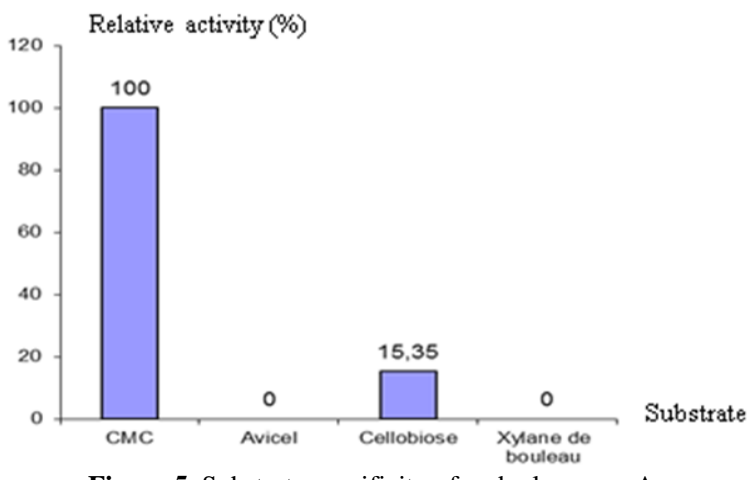

Figure 5 Substrate specificity of endoglucanase A.

\section{Effect of metal ions and reagents on activity}

The endoglucanase from Streptomyces sp. strain BPNG23 was strongly stimulated by manganese $\left(\mathrm{Mn}^{2+}\right)$ with a relative activity of $305.4 \%$. The enzyme was also stimulated by $\mathrm{Cu}^{+2}, \mathrm{NH}^{+4}, \mathrm{Zn}^{+2}, \mathrm{Ca}^{+2}, \mathrm{Fe}^{+2}, \mathrm{Ni}^{+2}$ and $\mathrm{Co}^{+2}$, this may be due to the stabilization of the structure of the enzyme (table 2). Higher activity in the presence of $\mathrm{Mn}^{+2}$ and $\mathrm{Co}^{+2}$ ions was observed in the studies forAnabaena laxaendoglucanase(Gupta et al., 2012) and endoglucanase of Daldiniae schscholzii (Karnchanatat et al., 2008). However, an inhibitory effect by these two ions was observed for the endoglucanases of Penicillium purpurogenum (Lee et al., 2008) and Bacillus sp. (Yu, 2012).

The purified endoglucanase was inhibited by SDS, EDTA, and DTT. Inhibition by EDTA suggests that the enzyme was a metalloprotein. In addition, DTT was a purified endoglucanase inhibitor, suggesting that disulfide bridges are essential for enzymatic activity. The lack of inhibition by PMSF suggests that the serine residue does not play an important role in catalytic activity (Annamalai and Elayaraja, 2013). 
Table 2 Effect of metal ions and chemical reagents on the activity of endoglucanase A

\begin{tabular}{lccc}
\hline $\begin{array}{l}\text { Metal ions } \\
\text { and chemical } \\
\text { reagents }\end{array}$ & $\begin{array}{c}\text { Relative activity } \\
(\%)\end{array}$ & $\begin{array}{c}\text { Metal ions and } \\
\text { chemical } \\
\text { reagents }\end{array}$ & $\begin{array}{c}\text { Relative activity } \\
(\boldsymbol{\%})\end{array}$ \\
\hline $\mathbf{N o}$ & 100 & $\mathrm{Na}^{2+}$ & 90.67 \\
\hline $\mathbf{C a}$ & 115.09 & $\mathrm{Fe}^{2+}$ & 136.02 \\
\hline $\mathbf{M g}^{2+}$ & 97.79 & $\mathrm{Sr}^{2+}$ & 99.87 \\
\hline $\mathbf{Z n}^{2+}$ & 110.6 & $\mathrm{Ni}^{2+}$ & 111.83 \\
\hline $\mathbf{N H}^{4+}$ & 149.42 & $\mathrm{Co}^{2+}$ & 117.14 \\
\hline $\mathbf{H g}^{2+}$ & 107 & $\mathrm{PMSF}$ & 105.68 \\
\hline $\mathbf{C u}^{2+}$ & 152.75 & $\mathrm{DTT}$ & 80.7 \\
\hline $\mathbf{K}^{+}$ & 96.83 & $\mathrm{SDS}$ & 86.55 \\
\hline $\mathbf{M n}^{2+}$ & 305.4 & $\mathrm{EDTA}$ & 87.36 \\
\hline
\end{tabular}

\section{Kinetic parameters}

The Km value is an amount from substrate necessary to achieve the half of initial maximum speed of enzyme; it is also a measurement from the apparently affinity from enzyme of its substrate.

The endoglucanase activity of the Streptomyces sp. strain BPNG23 was strongly influenced by the substrate concentration.

A Lineweaver-Burk plot for the activity indicated that the $\mathrm{km}$ value of the enzyme to carboxymethyl cellulose was $6.37 \mathrm{mg} \mathrm{mL}^{-1} ; \mathrm{V}_{\max }$ of this enzyme was $0.056 \mu \mathrm{mol} \mathrm{mn^{-1 }}$. The endoglucanase with a lower $K_{m}$ for carboxymethyl cellulose indicates a greater affinity for this substrate.

The $\mathrm{K}_{\mathrm{m}}$ values of endoglucanase reported were $3.6 \mathrm{mg} \mathrm{mL}^{-1}$ for Pseudomonas fluorescens (Bakare et al., 2005), $4.97 \mathrm{mg} \mathrm{mL}^{-1}$ for the Actinobacteria anitratus strain, and $7.90 \mathrm{mg} \mathrm{mL}^{-1}$ for Branhamella sp (Ekperigin, 2007). Theberge et al., 1992 reported that the endoglucanase of Streptomyces lividans has a $V_{\max }$ of 24.9 $\mathrm{U} \mathrm{mg}$ and $\mathrm{K}_{\mathrm{m}}$ of $4.2 \mathrm{mg} \mathrm{mL}^{-1}$.

\section{CONCLUSION}

Streptomyces sp. strain B-PNG23 was selected for its important productions of endoglucanases. Purification of the endoglucanase of the B-PNG23 strain needed three steps of purification: ultrafiltration, which gives a specific activity of 23.11 and a purification factor of 12.76; anion exchange chromatography which was the main step in the purification procedure, three endoglucanases were detected and eluted at different $\mathrm{NaCl}$ concentrations, at this phase the purification yield was greater than 14; molecular sieving which followed the anion exchange chromatography step allowed to increase the specific activity $(380.65 \mathrm{U} / \mathrm{mg})$, thus eliminating a very large part of protein contaminants. The enzyme purified was found to be active in a broad range of $\mathrm{pH}$ and temperature, which suggests that the enzyme from this strain could be used in the bioconversion to fermentable sugars of lignocellulosic biomass.

Acknowledgments: This study was financially sustained by Directorate-General for Scientific Research and Technological Development (DGRSDT)/ CNEPRU Project, $\mathrm{N}^{\circ}$ F00620140027.

\section{REFERENCES}

ANNAMALAI, N., MAYAVAN, V., SIVARAMASAMY, E. (2013). Thermostable, haloalkaline cellulase from Bacillus halodurans CAS 1 by conversion of lignocellulosic wastes. Carbohydrate Polymers 94 (1), 409-415. https://doi.org/10.1016/j.carbpol.2013.01.066

BIJENDRE, KB., HIMANI, P., MASOOD, A., PRIYANKA S, AJAY, S.(2009). Partial purification and characterization of a highly thermostable and $\mathrm{pH}$ stable endoglucanase from a newly isolated Bacillus strain M-9.Indian Journal of Chemical Technology, 16, 382-387. http://nopr.niscair.res.in/handle/123456789/6161

BAKARE, MK., ADEWALE, IO., AJAYI, A., SHONUKAN, OO. (2005) Purification and characterization of cellulase from the wild-type and two improved mutants of Pseudomonas fluorescens. African Journal of Biotechnology,

https://www.ajol.info/index.php/ajb/article/view/71111

BATAILLON, MA., NUNES, C., CASTILLON, N., DUCHIRON, F. (2000) Purification and Characterization of a Moderately Thermostable Xylanase from Bacillussp. Strain SPS-0. Enzyme and Microbial Technology, 26(2), 187-192. https://doi.org/10.1016/S0141-0229(99)00143-X

BATTAN, B., JITENDER, S., SAURABH, S., RAMESH, C. (2007). Enhanced production of cellulase-free thermostable xylanase by Bacillus pumilus ASH and its potential application in paper industry. Enzyme and Microbial Technology, 41,733-739. https://doi.org/10.1016/j.enzmictec.2007.06.006

BEG, Q., KAPOOR, M., MAHAJAN, L., HOONDAL, G. (2001). Microbial xylanases and their industrial applications: a review. Applied Microbiology and Biotechnology,56(3), 326-338. https://doi.org/10.1007/s002530100704

BÉGUIN, P., JEAN-PAUL, A. (1994). The biological degradation of cellulose.
FEMS Microbiolog 6976.1994.tb00033.x

BETTACHE, A., MESSIS, A., COPINET, E., KECHA, M., BOUCHERBA, N., BELHAMICHE, N., DUCHIRON, F., BENALLAOUA, S. (2013). Optimization and partial characterization of endoglucanase produced by Streptomyces sp. BPNG23. Archives of Biological Sciences Belgrade,65 (2), 549-58. https://doi.org/10.2298/ABS1302549A

BIELY, P., MACKENZIE, CR. (1986). Cooperativity of esterases and xylanases in the enzymatic degradation of acetyl xylan. Bio/Technology 4 (8), 731-733. https://doi.org/10.1038/nbt0886-731

BLANCO, A., PILAR, D́., JESÚS, Z., PALMA, P., JAVIER PASTOR, FI (1999). A Multidomain xylanase from a Bacillussp. with a region homologous to thermostabilizing domains of thermophilic enzymes. Microbiology 145 (8), 2163-2170. https://doi.org/10.1099/13500872-145-8-2163

BRADFORD, M.(1976). A rapid and sensitive method for the quantitation of microgram quantities of protein utilizing the principle of protein-dye binding Analytical Biochemistry, 72 (1-2), 248-254. https://doi.org/10.1016/00032697(76)90527-3

BUDIHAL, SR., DAYANAND, A., SARVAMANGALA, RP. (2016) Bioresource technology enhanced production and application of acidothermophilic Streptomyces cellulase. Bioresource Technology, 200, 706712. http://dx.doi.org/10.1016/j.biortech.2015.10.098

CAVACO-PAULO, A. (1998). Mechanism of cellulase action in textile $\begin{array}{lllll}\text { processes.Carbohydrate } & \text { Polymers, } & 37 & \text { (3), 273-277. }\end{array}$ https://doi.org/10.1016/S0144-8617(98)00070-8

CELESTINO, KR, CUNHA, RB., FELIX, CR. (2006). Characterization of a $\beta$ glucanase produced by Rhizopus microsporusvar. microsporus, and its potential for application in the brewing industry. BMC Biochemistry,5, 7-23 https://doi.org/10.1186/1471-2091-7-23

TAKASHIMA, S., IIKURA, H., NAKAMURA, A., HIDAKA, M., MASAKI, H., UOZUMI T. (1998). Isolation of the gene and characterization of the enzymatic properties of a major exoglucanase of Humicola grisea without a cellulose-binding domain. Journal of Biochemistry, 124(4), 717-725. https://doi.org/10.1093/oxfordjournals.jbchem.a022172

EKPERIGIN, MM. (2007). Preliminary studies of cellulase production by Acinetobacter anitratus and Branhamella sp. African Journal of Biotechnology, 6 (1), 28-33.https://www.ajol.info/index.php/ajb/article/view/56088

GEORGE, SP., ABSAR, A., MALA, BR. (2001). Studies on carboxymethyl cellulase produced by an alkalothermophilic actinomycete. Bioresource Technology, 77(2), 171-175. https://doi.org/10.1016/S0960-8524(00)00150-4

GOBALAKRISHNAN, R., KANNAN, S. (2017). Systematic characterization of potential cellulolytic marine Actinobacteria actinoalloteichussp. MHA15. Biotechnology Reports, 13, 30-36. https://doi.org/10.1016/j.btre.2016.12.003 PRINCE, S., GUPTA, JK.,VADEHR, DV.,DUBE, DK. (1990). Purification and properties of an endoglucanase from a Bacillus Isolate. Enzyme and Microbial Technology, 12(2), 132-137. https://doi.org/10.1016/0141-0229(90)90087-7

GUPTA, V., RADHA, P., VIDHI, C., LATA, N. (2012). Biocatalysis and agricultural biotechnology biochemical, structural and functional characterization of two novel antifungal endoglucanases from Anabaena laxa. Biocatalysis and Agricultural Biotechnology 1(4), 338-347. https://doi.org/10.1016/j.bcab.2012.08.001

KARNCHANATAT, A., AMORN, P., POLKIT, S., JITTRA, P., ANTHONY, J., WHALLEY, S., COLIN, DR., GEOFFREY, MG., PRAKITSIN, S. (2008). A novel thermostable endoglucanase from the wood-decaying fungus Daldinia eschscholzii. Rehm. Enzyme and Microbial, 42(5), 404-413. https://doi.org/10.1016/j.enzmictec.2007.11.009

DONG, WK., YOUNG, KJ.,YOUNG, HJ., JAE, KL. (1994). Purification and characterization of endoglucanase and exoglucanase components from Trichoderma viride. Journal of Fermentation and Bioengineering,77(4), 363369. https://doi.org/10.1016/0922-338X(94)90005-1

KUMAR, P., RYAN, B., HENEHAN, GTM. (2017).ק-Glucosidase from Streptomyces griseus: Nanoparticle immobilisation and alkyl

glucoside synthesis. Protein Expression and Purification. 132, 164-170. https://doi.org/10.1016/j.pep.2017.01.011

LEE, Y., BO-KYUNG, K., BO-HWA, L., KANG-IK, J., NAM-KYU, L., CHUNG-HAN, C., YOUNG-CHOON, L., JIN-WOO, L. (2008). Purification and Characterization of Cellulase Produced by Bacillus amyoliquefaciens DL-3 Utilizing Rice Hull. Bioresource Technology, 99: 378-386. https://doi.org/10.1016/j.biortech.2006.12.013

LINDENMUTH, BE., KAREN, AM. (2011). Production and characterization of Acidothermus cellulolyticus endoglucanase in Pichia pastoris. Protein $\begin{array}{llll}\text { Expression and Purification, } 77 \text { (2), 153-158 } & \end{array}$ https://doi.org/10.1016/j.pep.2011.01.006

LUCAS, R., ROBlES, A., GARCÍA, MT., ALVAREZ, DCG., GÁlVEZ, A. (2001). Production, purification, and properties of an endoglucanase produced by the hyphomycete Chalara (Syn. Thielaviopsis) paradoxa CH32. Journal of Agricultural and Food Chemistry,49(1), 79-85. https://doi.org/10.1021/jf000916p MAHESHWARI, R., GIRISH, B., MAHALINGESHWARA, KB. (2000). Thermophilic Fungi: Their Physiology and Enzymes. Microbiology and $\begin{array}{lllll}\text { molecular biology } & \text { reviews, } & 64 & \text { (3), } & 461-488\end{array}$ 
https://doi.org/10.1128/MMBR.64.3.461-488.2000

MANDELS, M. (1985). Applications of cellulases. Biochemical Society Transactions 13 (2), 414-16. https://doi.org/10.1042/bst0130414

SCHREMPF, H. (2017).Elucidating biochemical features and biological roles 1 of Streptomyces proteins recognizing crystalline chitin- and cellulose-types and their soluble derivatives.Carbohydrate Research. 448, 220-226. https://doi.org/10.1016/j.carres.2017.06.010

SHAIK, M., GIRIJA, GS., ISWARYA, M, RAJITHA, P. (2017). Isolation and characterization of bioactive metabolites producing marine Streptomyces parvulus strain sankarensis-A10. Journal of Genetic Engineering and Biotechnology. 15 (1), 87-94. https://doi.org/10.1016/j.jgeb.2017.02.004

THEBERGE, M., PASCAL, L., FRANCOIS, S., ROLF, M., DIETER, K. (1992).

Purification and characterization of an endoglucanase from Streptomyces lividans 66 and DNA sequence of the gene. Applied and Environmental Microbiology,58 (3), 815-820. https://aem.asm.org/content/58/3/815.short

LAEMMLI, UK. (1970). Cleavage of structural proteins during the assembly of the head of bacteriophage T4.Nature, 227, 680-685. https://doi.org/10.1038/227680a0

WANG, Y., XIAONAN, W., RENTAO, T., SHANSHAN, Y., BAISONG, Z. YAN, F. (2010). A novel thermostable cellulase from Fervidobacterium nodosum. Journal of Molecular Catalysis B: Enzymatic, 66, 294-301. https://doi.org/10.1016/j.molcatb.2010.06.006

HAO, W., XIANBO, C., YONGFENG, Z., WEI, Z., GUIGUANG, C., ZHIQUN

L. (2017). Purification and characterization of a cellulase-free, thermostable endo-xylanase from Streptomyces griseorubens LH-3 and its use in biobleaching on eucalyptus kraft pulp. Journal of Bioscience and Bioengineering,125(1),4651. https://doi.org/10.1016/j.jbiosc.2017.08.006

YAZDI, MT., RADFORD, A., KEENS, JN., WOODWARD, JR. (1990) Cellulase production by Neurospora crassa: Purification and characterization of cellulolytic enzymes. Enzyme and Microbial Technology, 12(2),120-123. https://doi.org/10.1016/0141-0229(90)90084-4

XIN, L., HUI-YING, Y. (2012). Purification and characterization of an organicsolvent-tolerant cellulase from a Halotolerant Isolate, Bacillus sp . L1. Journa of Industrial Microbiology and Biotechnology, 39, 1117-1124. https://doi.org/10.1007/s10295-012-1120-2 